\title{
Corrigendum to "Plasma Albumin Induces Cytosolic Calcium Oscilations and DNA Synthesis in Human Cultured Astrocytes"
}

\author{
Lorena Vega-Zelaya, ${ }^{1}$ Ivan Herrera-Peco, ${ }^{2}$ Guillermo J. Ortega, ${ }^{3}$ \\ Rafael G. Sola, ${ }^{3}$ and Jesús Pastor ${ }^{1}$ \\ ${ }^{1}$ Clinical Neurophysiology, The Epilepsy Unit, University Hospital La Princesa, Calle de Diego León 62, 28006 Madrid, Spain \\ ${ }^{2}$ Fundación para el Desarrollo de la Enfermería (FUDEN), C/Veneras, 9, 28013 Madrid, Spain \\ ${ }^{3}$ Neurosurgery, The Epilepsy Unit, University Hospital La Princesa, 28006 Madrid, Spain
}

Correspondence should be addressed to Jesús Pastor; jesus.pastor@salud.madrid.org

Received 6 April 2016; Accepted 5 May 2016

Copyright (C) 2016 Lorena Vega-Zelaya et al. This is an open access article distributed under the Creative Commons Attribution License, which permits unrestricted use, distribution, and reproduction in any medium, provided the original work is properly cited.

In the article titled "Plasma Albumin Induces Cytosolic Calcium Oscilations and DNA Synthesis in Human Cultured Astrocytes", [1] Dr. Ivan Herrera-Peco was missing from the author list. The corrected author list and affiliations are shown above. Consequently, the following should have been added: Lorena Vega-Zelaya and Ivan Herrera-Peco contributed equally to this paper.

In addition, the word "Oscilations" is misspelled in the article title and should be corrected as "Oscillations."

\section{References}

[1] L. Vega-Zelaya, G. J. Ortega, R. G. Sola, and J. Pastor, "Plasma albumin induces cytosolic calcium oscilations and DNA synthesis in human cultured astrocytes," BioMed Research International, vol. 2014, Article ID 539140, 10 pages, 2014. 


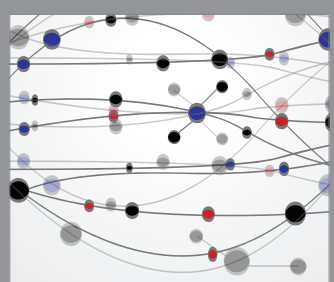

The Scientific World Journal
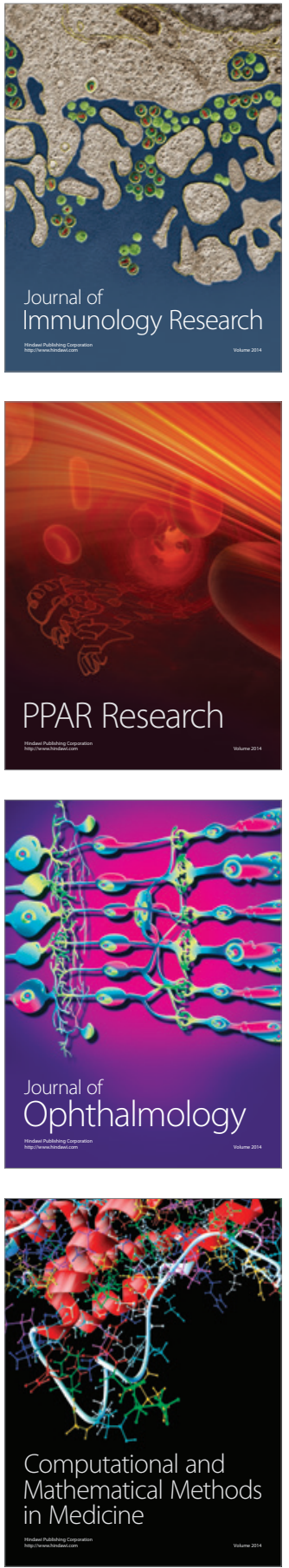

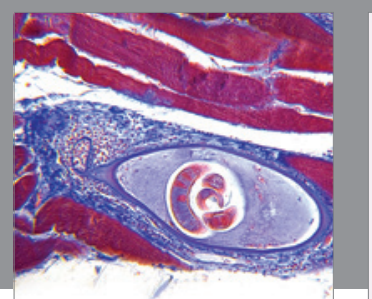

Gastroenterology Research and Practice

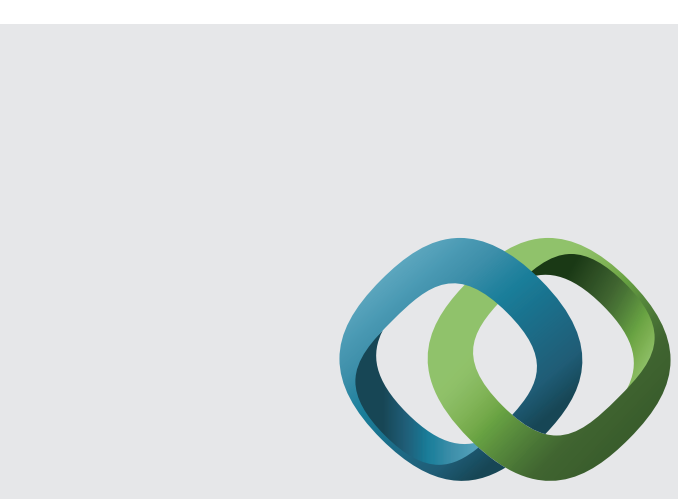

\section{Hindawi}

Submit your manuscripts at

http://www.hindawi.com
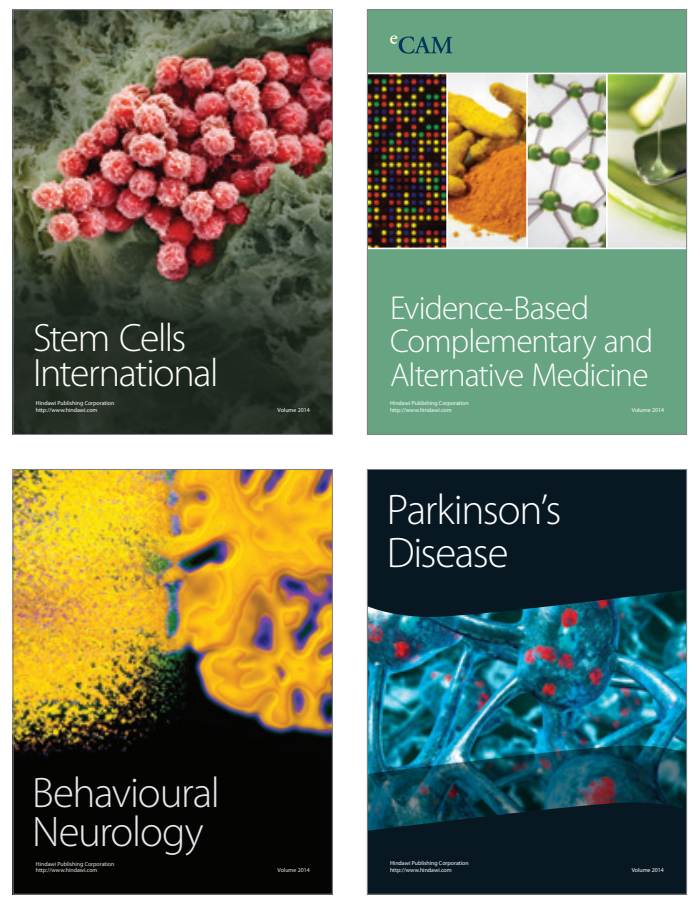
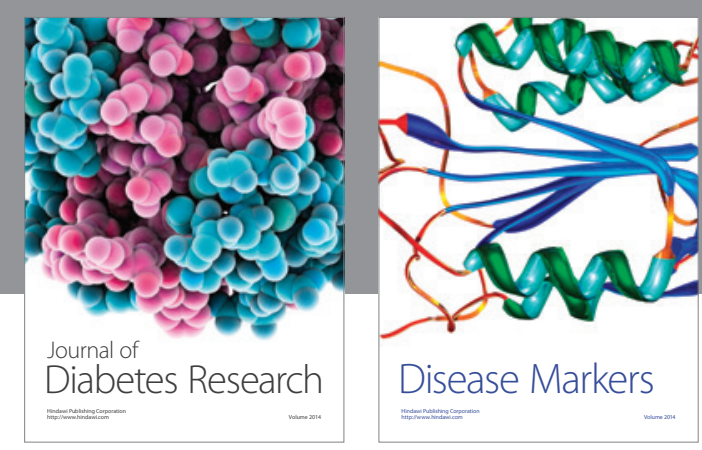

Disease Markers
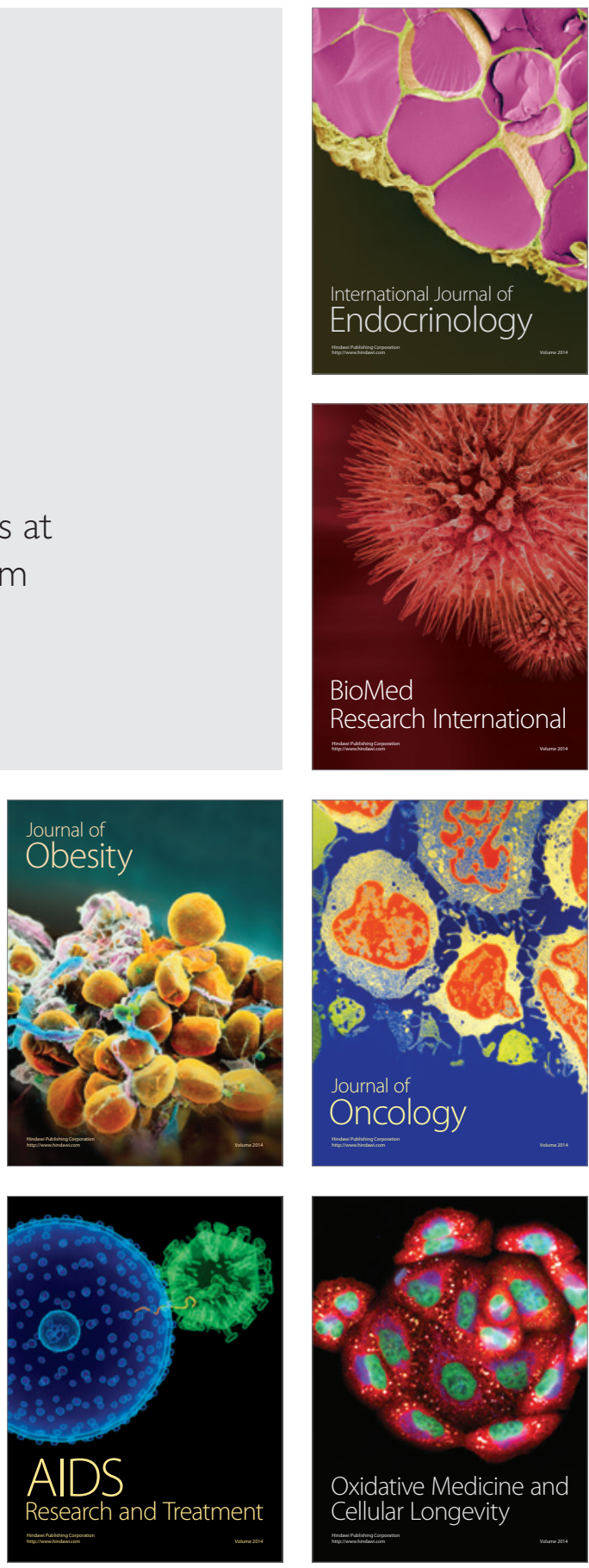